\title{
Association Between Leadership Practices and Self-Efficacy of Personnel
}

\author{
Saghir Ahmad \\ PhD Scholar, Institute of Education and Research, University of the Punjab, Lahore Pakistan.
}

\author{
Dr. Ayesha Batool \\ Assistant Professor, The Department of Education, Lahore College for Women University, Lahore Pakistan.
}

\begin{abstract}
The student achievement is the direct outcome of the effort expended by the teachers in the classroom. To get the teachers engaged in the classroom efficiently and diligently it is very necessary to provide them with a conducive and favorable working environment in school for which only the head teachers is capable and responsible to achieve the highest level of success. Teachers' self-efficacy is affected directly by the head teachers' leadership practices. This study was designed to explore the correlation between head teachers' leadership practices and teachers' self-efficacy. Correlation research design was used to conduct this study by applying survey method. The population of the study was consisted of secondary schools teachers. A sample of two hundred students was selected by conveniently sampling technique. Researchers collected data by self-developed questionnaire on five point likert scale related to leadership practices and teachers' self-efficacy. There was significant positive moderate relationship between leadership practices and teachers self-efficacy. Both male and female teachers' had same perceptions about leadership practices and self-efficacy at secondary level. Head teachers may motivate and entice teachers positively to increase the level of teacher efficacy. Basic facilities may provide to the teachers to improve their self-efficacy.
\end{abstract}

Keywords: Heads' leadership practices, teachers' self-efficacy, motivation, and facilities

DOI: $10.7176 / \mathrm{JEP} / 10-16-07$

Publication date: June $30^{\text {th }} 2019$

\section{Introduction}

Leadership is a procedure and way towards getting the personnel work adequately and purposefully for the accomplishment of the mutual objectives. An individual having a dream pays his full energies to accomplish the common objectives and conveys the vision in such a way, that his devotees may comprehend and embrace that vision. The leader directs followers and gives them directions to have lucidity about standards and objectives of an association. Administration requests the individual to have the characteristics and character that may assist him with performing his activity adequately and he should display attributes and practices that are activities and employees focused. Leader may use both the methodologies choosing as indicated by the requests of the circumstance and necessities of the job (Robbins \& Coulter, 2006; Robbins \& Sanghi, 2006).

The impact of principal leadership styles plays a compelling and critical job in affecting the school conditions and educators work relating to students' accomplishment and effectiveness of institution. Schools where the leading man can move his partners to make progress toward the accomplishment of shared goals, conveys his vision in an expressive and viable way, advances a culture of trust and regard, and gives teachers an incredible feeling of efficacy. Leaders who use their endeavors to give assets to faculty members and make a climate conductive to learning and permit them self-rule over class issues and give them a chance to take an interest in basic leadership, enhance the level of viability and self-efficacy (Tschnnen-Moran \& Hoy, 2007).

Transformational leaders furnish the instructors with provoking condition to demonstrate their capacities, urge them to take activities and increment their activity fulfillment which goes about as a significant impetus to raise instructors' self-viability level (Nir \& Kranot, 2006). Leadership approaches which principals adopt have direct association with educators' self-viability, work fulfillment and inspiration. Self-efficacy beliefs might be developed by the leader possessing the transformational characteristics and furthermore giving attention and individuals centered leader. The profoundly energetic and satisfied staff, being upheld by their head of department, and who trust their head instructor to utilize his capacity for the mentors' advantages and prosperity, this sort of authoritative condition or leadership approach contributes towards enhancing the teachers' selfefficacy regarding teaching (Leithwood, 1994). Transformational leadership approach of leaders and emblematic types of instructional administration positively affect teachers' inspiration and the adequacy convictions and this thing provoke faculty members to work more diligently to accomplish more capability and achievements (Hipp, 1997).

Leaders can enhance the self-efficacy level of personnel through set mission and making and conveying a vision persuasively and motivating them to use their energies for the achievement of that vision and by making a shared basic leadership culture, in which they take part in decision making. The head of institution is liable of 
providing healthy and satisfy environment to followers for the sake of gaining their attention towards work. Comfortable environment allows staff to put their efforts with positive mind to attain goals. Leader gives great workplace and empathetic consideration to overcome the deficiencies. This kind of leaders can make the faculty viable enough through verbal influence, team work and by furnishing the instructors with chances to practice the activities of their effective partners (Ross \& Gray, 2004).

The idea of self-adequacy has been characterized as a recognition or conviction of an individual about his capacity to coordinate social, intellectual and conduct abilities so as to compose and do the important actions to the ideal outcomes. Self-efficacy is also named as the judgment of an individual or individual about their capacities to play out an activity in such a way, that the required standard of accomplishment and execution is come to (Bandura, 1986, 2000, 2001).

Instructor self-viability has been characterized as the judgment of the capacity to incorporate social intellectual and conduct abilities so as to compose and do the game-plans important to accomplish the ideal outcomes (Zimmerman, 2000). Bandura (1997) narrated educator viability to the origination of authority encounters, stating that the strong instructors can make circumstances by giving worthwhile dominance encounters to their learners and they approach requesting or extreme study halls conditions with a critical thinking approach. He further included that teachers having low efficacy and are not strong in teaching efficacy, they are unable to manage classrooms effectively and efficiently. They cannot handle the class issue meritoriously.

\section{Significance of Study}

Educators' self-adequacy beliefs cast an immediate and incredible impact on learners' learning and accomplishment and for the duration of their lives. The achievement of the entire training framework depends on instructing staff. Various elements from inside and outside of the instructive framework continue giving gainful a role as well as dangerous endeavors on the self-adequacy decisions of the teachers. However, the policy makers and school organization usually concentrate on monetary and money related motivating forces for the instructors as opposed to paying due thought to enlarge the self-viability beliefs of the educators which they gain from their competency in conveying profitable expert administrations to maintain their excitement and to contribute adequately and productively towards students' achievement. The findings of study help out in investigating the leadership behaviors and practices of the school leaders. The results may help the head educators embrace such leadership approaches that are strong of reinforcing instructors' self-adequacy beliefs, which would result in better learners' accomplishment. The study might be useful in investigating the systems to raise the self-viability dimension of the teachers. The main advantage of the study might be to improve learners learning and accomplishment through raising the educators' self-viability and inspiration level and contributing towards their expert development. It will be a profitable expansion in the current assemblage of information in regards to the leadership practices of the head educators and its association with self-efficacy of teachers.

\section{Research Objectives}

The following were objectives of the study:

1. Explore the relationship between head teachers' leadership practices and self-efficacy of teachers in schools.

2. Compare differences among teachers' perceptions about leadership practices and self-efficacy on the basis of demographic variables.

\section{Research Methodology}

A descriptive study was designed to investigate the relationship between head teacher leadership practices and teachers self-efficacy. The survey method was adopted to gather data from the secondary school teachers. The Population for this study consisted of secondary school teachers of Lahore. The convenient sampling procedure was used to select the sample. The data were collected from 200 school teachers $(100$ male and 100 female teachers). The questionnaire used for the study was developed by the researchers. The opinion of experts was taken for the validation of questionnaire before finalizing. Questionnaire was developed for the teacher's opinion on the head teacher leadership practices and teacher self-efficacy. There were 30 statements related to head teacher leadership practices and teacher self-efficacy. All statements designed at five-point Likert scale. Internal consistency was also measured by applying cronbach alpha. Reliability value of instrument was under in following table.

Table 1

Reliability of Instrument

Cronbach's Alpha $\quad$ No. of Items

$.858 \quad 30$

The Cronbach's Alpha was applied to check the reliability of the study. There were 30 statements in the 
questionnaire and reliability value was .858 . The Cronbach's Alpha value shows that instrument is reliable.

The researchers visited the schools for data collection. Data were collected from different public secondary school teachers. Statistical techniques were applied to analyze the data. Pearson $r$ used to calculate the relationship between head teachers leadership practices and teachers' self-efficacy. Independent samples t-test and one way ANOVA were used to check the difference in teachers' opinions regarding leadership practices and self-efficacy scores on the basis of demographic variables.

\section{Data Analysis}

The detail of data analysis is given below.

Table 2

Demographic Information of Respondents

\begin{tabular}{llcc}
\hline Variables & & Frequency & Percent \\
\hline Gender & Female & 100 & 50.0 \\
& Male & 100 & 50.0 \\
Age & Total & 200 & 100.0 \\
& Above46 & 36 & 18.0 \\
& $36-45$ & 139 & 69.5 \\
\multirow{3}{*}{ Education } & $25-35$ & 25 & 12.5 \\
& Total & 200 & 100.0 \\
& M.Phil. & 57 & 28.5 \\
& M.A/ M.Ed. & 122 & 61.0 \\
& BS/B.Ed. 4 years & 21 & 10.5 \\
& Total & 200 & 100.0 \\
\hline
\end{tabular}

Table 3

Correlations between Heads Teachers Leadership Practices and Teachers' Self-efficacy

\begin{tabular}{llc}
\hline Variables & & Teachers Self-Efficacy \\
\hline Leadership Practices & Pearson Correlation & $.306^{* *}$ \\
& Sig. (2-tailed) & .000 \\
& $\mathrm{~N}$ & 200 \\
\hline
\end{tabular}

Table shows that Pearson $r$ was applied to check association between two variables. There was significant positive moderate relationship between leadership practices and teachers self-efficacy $(r=.306, p<.05)$.

Table 4

Difference in Male and Female Teachers' Perceptions regarding Leadership Practices and Self-Efficacy

\begin{tabular}{llcccccc}
\hline Variables & Gender & $N$ & Mean & $S D$ & $t$ & $d f$ & $p$ \\
\hline Leadership Practices & Male & 100 & 56.91 & 6.594 & .671 & 198 & .503 \\
& Female & 100 & 56.29 & 6.472 & & & \\
Self-Efficacy & Male & 100 & 59.42 & 6.783 & .456 & 198 & .649 \\
& Female & 100 & 58.96 & 7.459 & & & \\
\hline
\end{tabular}

An independent sample t-test was applied to find the gender difference. The results revealed that gender difference does not exist in perceptions of teachers towards heads leadership practices, $t(198)=.503, p>.05$. Further, findings showed that there was no gender difference in perceptions of teachers towards self-efficacy, $t$ $(198)=.649, p>.05$. It is concluded that both male and female teachers' had same perceptions about leadership practices and self-efficacy at secondary level.

Table 5

One way ANOVA to Check Age Difference of Respondents

\begin{tabular}{llccccc}
\hline Variables & & Sum of Squares & $d f$ & Mean Square & $F$ & Sig. \\
\hline Leadership Practices Between Groups & 653.356 & 2 & 326.678 & 8.233 & .000 \\
& Within Groups & 7816.644 & 197 & 39.678 & & \\
\multirow{5}{*}{ Self-Efficacy } & Total & 8470.000 & 199 & & & \\
& Between Groups & 1661.129 & 2 & 830.565 & 19.452 & .000 \\
& Within Groups & 8411.651 & 197 & 42.699 & & \\
\hline
\end{tabular}

Table shows that one way ANOVA was applied to find the age difference. The results revealed that age difference is exist in perceptions of teachers regarding leadership practices, $F(2,197)=8.233, p<.05$; and teachers self-efficacy, $F(2,197)=19.425, p<.05$. It is concluded that teachers' having various age groups (25$35,36-45,>46)$, had different attitude towards heads leadership practices and teachers self-efficacy at secondary level. The post-hoc test applied to post-hoc test applied to find the difference between groups and within groups. 
Table 6

LSD Multiple Comparisons to Find the Age Difference between Groups and within Groups

\begin{tabular}{lccccc}
\hline Dependent Variable & (I) Age & (J) Age & Mean Difference (I-J) & Std. Error & Sig. \\
& & & & & \\
\hline Leadership Practices & $25-35$ & $36-45$ & $3.194^{*}$ & 1.368 & .021 \\
& & $>46$ & $6.556^{*}$ & 1.640 & .000 \\
& $36-45$ & $25-35$ & $-3.194^{*}$ & 1.368 & .021 \\
& & $>46$ & $3.361^{*}$ & 1.178 & .005 \\
Self-Efficacy & $>46$ & $25-35$ & $-6.556^{*}$ & 1.640 & .000 \\
& & $36-45$ & $-3.361^{*}$ & 1.178 & .005 \\
& $25-35$ & $36-45$ & $8.398^{*}$ & 1.420 & .000 \\
& & $>46$ & $4.741^{*}$ & 1.701 & .006 \\
& \multirow{2}{*}{$36-45$} & $25-35$ & $-8.398^{*}$ & 1.420 & .000 \\
& & $>46$ & $-3.657^{*}$ & 1.222 & .003 \\
& $>46$ & $25-35$ & $-4.741^{*}$ & 1.701 & .006 \\
\end{tabular}

The post-hoc test results in table above describe that teachers' having age range 25-35, significantly differed in their perceptions from those teachers' who 36-45 years $\left(3.194^{*}\right)$ and above 46 years age $\left(5.556^{*}\right)$.

\section{Discussion}

The present study shows that self-efficacy differences exist significantly among male and female secondary school teachers and there is significant relationship between leadership practices of head teachers and teachers' self- efficacy. The results of the present study are also in conformism with the results of the study carried out by Hipp (1997) who concluded that principals' leadership practice influenced teachers' work and it influences through the impact on teachers' self- efficacy beliefs. The result of the study are also in line with the result of study by Ross and Gray (2004) to explore the relationship of principal leadership behaviors with teachers' selfefficacy in elementary school. Findings of both studies showed that there is positive association between leadership practices and self-efficacy of teachers.

\section{Conclusion}

The purpose of this study was to determine the relationship between head teacher leadership practices ad teacher self-efficacy at secondary school level. The concept of leadership has been researched abundantly in different cultural context. The concept of teachers' self-efficacy has also been researched. With an increasing dissatisfaction prevailing among teachers and the poor performance of the students at secondary level, attention must be given to the role that head teacher leadership practices play in raising the efficacy and motivation. Principals leading style positively influence the self-efficacy of teachers. Thus, they may remain to improve their work to better address the varied needs of students. The design of study was correlation and survey type in nature and research participants were teachers of secondary school. It was found that there is a relationship between head teacher leadership practices and teacher self- efficacy. If head teacher motivate and support teachers work then their self -efficacy level improve in schools. The findings showed that there was significant positive moderate relationship found between leadership practices and teachers self-efficacy. The results revealed that gender difference does not exist in perceptions of teachers towards heads leadership practices and teachers' self-efficacy. It is concluded that both male and female teachers' had same perceptions about leadership practices and self-efficacy. It is concluded that teachers' having various age groups had different attitude towards heads leadership practices and teachers self-efficacy and perceive things differently.

\section{Recommendations}

Researchers made some following recommendations on the basis of findings of study.

1. Pre-service and in-service training courses and workshops may be conducted to enhance relationship between head teacher leadership practices and teacher self-efficacy at secondary school.

2. The future research may be extended to studying both private and public sector schools.

3. The future studies may also be conducted in primary and middle schools.

4. Head teachers may motivate and entice teachers positively to increase the level of teacher efficacy. Basic facilities may provide to the teachers to improve the teacher self-efficacy.

5. Democratic leadership style may implement in schools because this help to increase relationship between head teacher and teacher self-efficacy.

\section{References}

Bandura, A. (1977). A social learning theory. Englewood Cliffs, New Jersey: prentice Hall. 
Bandura, A. (1986). Social foundations of thought and action: A social cognitive theory. Englewood Cliffs, New Jersey: Prentice Hall.

Bandura, A. (2000). Cultivate self-efficacy for personal and organizational effectiveness. In E. A. Locke (Ed.), Handbook of principles of organizational Behavior. Oxford, U.K.: Blackwell.

Bandura, A. (2001). Social cognitive theory: An argentic perspective. Annual Review of Psychology, 52, 1-26.

Hipp, K. A. (1997). Documenting the effects of transformational leadership behavior on teacher efficacy. Paper presented at the annual meeting of the American Educational Research Association, Chicago, II.

Leithwood, K. (1994). Leadership for school restructuring. Educational Administration Quarterly, 30(4), 498518

Nir, A. E., \& Kranot, N. (2006). School principal's leadership style and teachers' self-efficacy. Planning and Changing, 17(3\&4), 205-218.

Robbins, S. P., \& Coulter, M. (2006). Management (8th ed.). New Jersey: prentice-Hall.

Robbins, S. P., \& Sanghi, S. (2006). Organizational behavior (1 ${ }^{\text {st }}$ ed.). Delhi, Dorling Kindersley (India) Pvt. Ltd. Rosenholtz, S. J. (1989). Teachers' workplace: The social organization of schools. New York: Longman.

Ross, J. A., \& Gray, P. (2004). Transformational leadership and teacher commitment to organizational values: The mediating effects of collective teacher efficacy. Paper presented at the annual meeting of the American Educational Research Association, San Diego.

Ross, J. A., Hogaboam-Gray, A., \& Hannay, L. (2001). Effects of self-efficacy on computer skills and computer cognitions of K-3 students. Elementary School Journal 102, 141-156.

Tschannen-Moran, M., \& Hoy, A. W. (2007). The differential antecedents of self-efficacy beliefs of novice and experienced teachers. Teaching and Teacher Education, 23, 944-956.

Zimmerman, B. J. (2000). Self-efficacy: An essential motive to learn. Contemporary Educational Psychology, $25,82-91$ 